\title{
Prolactin gene and laying performance in aseel birds
}

\begin{abstract}
Prolactin gene polymorphism at exon 5 of prolactin receptor gene (PRLR5) was studied in Aseel birds along with its interaction with laying performance. Laying performances were recorded as age at first laying (AFE), Body Weight at First Egg (WFE), Mean Egg Weight (MEW) and Total No. of Eggs at 90 days of laying (TEN). DNA was isolated from 2- $3 \mathrm{ml}$ not clear of Blood from 40 birds collected from wing vein. PRLR5 locus was amplified by PCR and the product was restriction digested with Bam HI and resolved on 2\% Agarose gels for genotyping. The AFE (d), WFE (Kg), MEW (g) and TEN of Aseel birds in the present study were found to be $188.40 \pm 0.22$, $1.57 \pm 0.03,43.61 \pm 0.36 \& 35.48 \pm 0.40$ respectively. The prolactin gene locus PRLR5 showed two alleles A \& B. The frequencies of A and B alleles at this locus were 0.60 and 0.40 respectively. There was no interaction of various laying performances found with alleles of PRLR5.
\end{abstract}

Keywords: egg production performance, kadaknath, prolactin, polymorphism, birds
Volume 3 Issue I - 2018

\author{
Maurya SK,' Yadav BM ${ }^{2}$ \\ 'Narendra Deva University of Agriculture \& Technology, India \\ ${ }^{2}$ Nawab Wajid Ali Shah Zoological Garden, India \\ Correspondence: SK Maurya, Deparment of Veterinary \\ Physiology \& Biochemistry, College of Veterinary Science \& \\ Animal Husbandry, Narendra Deva University of Agriculture \\ Technology, Kumarganj, Faizabad- 224229 (UP) India, Tel \\ +919415720187, Email skmaurya@yahoo.com
}

Received: December 29, 2017 | Published: February 15, 2018
Abbreviations: MEW, mean egg weight; WFL, weight at first laying; AFH, age of hens; MEW, mean eggs weight; TEN, total number of eggs

\section{Introduction}

Egg productivity is the most important economic trait in egglaying poultry. Endocrine and environmental factors such as length of photoperiod and feeding allowance can influence egg production. However, a genetic factor would be a prerequisite. Egg production is a polygenic inheritance trait with low to moderate heritability depending on the period involved, a major opportunity for improvement in this trait lies in the period after 40 weeks of age., ${ }^{2,3}$ In traditional breeding, genetic improvement based on estimated breeding values requires extensive data from a variety of sources. Prolactin (PRL) is a polypeptide hormone which plays a key role in egg production. Onset of incubation behavior is induced by an increase in PRL secretion, which results in regression of ovary \& loss of egg production. ${ }^{4}$ Polymorphism in the promotor region specially those that result in change of promoter binding sites, most likely influence mRNA expression and thus influence incubation behavior and egg production. ${ }^{5}$ The Asil or Aseel is a breed of chicken originating from South Punjab/Sindh area of Pakistan and India. The Aseel breed is known for its stamina, pugnacity, majestic gait, and dogged fighting qualities. ${ }^{6}$ This breed is characterized by its hardiness and ability to thrive under adverse climatic conditions, and its meat is considered to have a desirable taste and flavor. The superiority of Aseel on other indigenous breeds is due to its hardiness, resemblance to Cornish and larger body size. ${ }^{7}$ Almost all the varieties of Aseel are characterized with heavy body weight and poor egg production potential thus leading to low progeny size due to erratic ovulation, short or erratic clutches and broodiness. Due to different biological activities attributed to PRL and PRLR, they can be used as the major candidate genes in molecular animal breeding programs. There is scarce data in case of breeds like Aseel, thus present study was planned.

\section{Materials and methods}

\section{Birds and production data}

The birds from the poultry farm of College of Veterinary Science
\& Animal Husbandry, Narendra Deva University of Agriculture \& Technology, Kumarganj, and Faizabad were used for the present study. Forty female birds of Aseel breed nearing their age of laying were taken for the present study. Birds were kept in separate cages for the ease of sample \& data collection and were fed ad libitum. The weights at first egg (WFE) were recorded in $\mathrm{kg}$ with a balance on the day when they gave their first egg. Age at first egg (AFE) was calculated from the records. Mean weight of eggs (MEW) was taken as average of daily egg weights over a period of 90 days of laying and recorded in $g$ with the help of a monopan balance. Total no. of eggs (TEN) represented the number of eggs laid over the study period of 90 days.

\section{Blood Collection and DNA isolation}

Two to three $\mathrm{ml}$ of blood was collected from wing vein of each bird in a vacutainer tube containing EDTA. DNA was isolated from $2-3 \mathrm{ml}$ of blood using High salt method of Montgomery and Sise ${ }^{8}$ with slight modifications.

\section{Polymerase chain reaction}

Polymerase chain reaction was carried out in a Bio-Rad CFX96 Real Time system. Primer pair for PRLR5 was used as described by Rashidi et al., ${ }^{9}$ to amplify a fragment of $250 \mathrm{bp}$ from exon 5 of prolactin receptor gene. The sequence of primers is as follows:

\section{Forward: 5'-TTGTCTGCTTTGATTCATTTCC-3'}

\section{Reverse: 5'-TGCATTTCATTCTTCCCTTTTT-3'}

PCR was performed in a final volume of $50 \mu$ l containing:100ng of genomic DNA, $0.5 \mu \mathrm{M}$ of each primer, $0.2 \mathrm{~mm}$ of each dNTPs, $1.5 \mathrm{mM}$ $\mathrm{MgCl} 2,1.0 \mathrm{U}$ Taq DNA polymerase and $1 \times$ reaction buffer. The cycle conditions for PCR included-Initial denaturation of $5 \mathrm{~min}$ at $94^{\circ} \mathrm{C}$; followed by 35 cycles of $94^{\circ} \mathrm{C}$ for $30 \mathrm{~s}$, annealing at $59^{\circ} \mathrm{C}$ for $60 \mathrm{~s}$, extension at $72^{\circ} \mathrm{C}$ for $60 \mathrm{~s}$ followed by a final extension of $5 \mathrm{~min}$ at $72^{\circ} \mathrm{C}$. The PCR product was resolved on to a $2 \%$ Agarose gel.

\section{Restriction digestion}

The fragment amplified by PRLR5 contains GGATC sequence for BamHI endonuclease. Thus, restriction enzyme BamHI was used. 
The restriction digestion was performed in $20 \mu$ l volume having $1 \mathrm{X}$ restriction enzyme buffer and 4-5 units of enzymes. The reaction tubes were incubated overnight at $37^{\circ} \mathrm{C}$.

\section{Genotyping and statistical analysis}

Genotypes were manually scored based on the bands resolved on the gel. Frequencies of various alleles were calculated using the following formula:

Frequency of an allele $=\frac{(2 \times \text { No.of Homozygote })+(\text { No.of Heterozygote })}{2 \times \text { Total no.of Individuals }(N)}$

Alleles frequency and their accordance to Hardy-Weinberg equilibrium were calculated from Graphpad Prism software version 5.0. The following linear equation was applied to analyze the genetic effects of PRL24:

$$
Y i j=\mu+G i+H j+e i j,
$$

Where Yij is the average performance of ith genotype in $\mathrm{j}^{\text {th }}$ hatch, $\mu$ is mean of the population, Gi is fixed effect of $i^{\text {th }}$ genotype $(i=1,2,3)$, $\mathrm{hj}$ is fixed effect of $\mathrm{jth}$ hatch $(\mathrm{j}=1,2,3)$, and eij is random residual error.

\section{Results and discussion}

The AFE in days in Aseel hens ranged from 184 to 194, whereas the Mean \pm SEM was found to be $188.40 \pm 0.22$. The weight at first laying (WFE) in $\mathrm{Kg}$ among Aseel hens ranged from 1.20 to 2.20; the mean \pm SEM being $1.57 \pm 0.03$. The mean egg weight (MEW) ranged from $39.97 \mathrm{~g}$ to $49.62 \mathrm{~g}$ and the mean \pm SEM values were found to be 43.61 \pm 0.36 . Total number of eggs (TEN) varied from 29 to 41 ; the mean being $35.48 \pm 0.40$. The age at first laying (AFE) in the present study was higher than the studies of Mohan et al. ${ }^{10}$ (2008a, b); where they reported it to be $154 \mathrm{~d}$. The body weights of Aseel hens (WFE) in the present study were better than the study of Gurung \& Singh; ${ }^{11}$ where they reported the body weights (g) to be $1133 \pm 1.52$ at an age of 6 months. This difference might be due to the fact that they studied this breed reared by the farmers/ localities as unorganized farms; whereas in the present study, birds were kept in organized farm of the University.

Similar findings regarding WFE were reported by Ahmad et al., ${ }^{12}$ in Peshawari variety of Aseel; whereas, mean eggs weight (MEW) and TEN in the present study, were better than previous study. ${ }^{11,13,14}$ These differences might be due to the difference in breed of Aseel hens and managemental conditions. There was present of only two alleles: one where the restriction site was present and other where restriction site was absent. The individuals showing no restriction site for the enzyme were designated as of BB genotypes; whereas AA genotypes were cut by the enzyme. The frequency of A allele was higher (0.60) than B allele (0.40) at PRLR5 marker site. These results are in concurrence with the findings of Rashidi et al. ${ }^{9}$ where they reported the frequencies of $\mathrm{AA}$ and $\mathrm{BB}$ genotypes to be 0.72 and 0.28 respectively. The age of hens at their first laying (AFE) in the genotypes AA \& BB were $186.8 \pm 0.69 \& 188.1 \pm 0.79$ respectively. The mean body weight at $1^{\text {st }}$ laying of hens (WFE) having genotypes AA $\&$ BB were $1.60 \pm 0.05 \& 1.53 \pm 0.04$ respectively. Birds showing mean egg weight (MEW) having genotypes AA \& BB were $43.20 \pm 0.45$ and $44.11 \pm 0.60$ respectively. All birds showing mean total no. of egg (TEN) having genotypes AA \& BB were $36.14 \pm 0.48$ \& $34.67 \pm 0.63$ respectively.

\section{Conclusion}

Statistically, there was no significant difference was found between the means of various laying traits with genotypes and this finding is in contrary to the findings of Zhang et al. ${ }^{15}$ where they found that polymorphism of the PRLR gene is significantly associated with egg production traits in the Erlang Mountainous chicken. This difference might be attributed to breed of birds used in the study. Based on the findings of current study, it can be concluded that though PRLR5 shows polymorphisms in Aseel hens, statistically there is no association of laying performance with polymorphism at this locus of Prolactin.

\section{Acknowledgements}

None.

\section{Conflict of interest}

The author declares no conflict of interest.

\section{References}

1. Lewis PD, Gous RM. Effect of final photoperiod and twenty-week body weight on sexual maturity and early egg production in broiler breeders. Poult Sci. 2006;85(3):377-383.

2. Emsley A. Integration of classical and molecular approaches of genetic selection: egg production. Poult Sci. 1997;76(8):1127-1130.

3. Luo PT, Yang RQ, Yang N. Estimation of genetic parameters for cumulative egg numbers in a broiler dam line by using a random regression model. Poult Sci. 2007;86(1):30-36.

4. Sharp PJ. Immunological control of broodiness. World Poult Sci J. 1997;53:23-31.

5. Cui JX, Du HL, Liang Y, et al. Association of polymorphisms in the promoter region of chicken prolactin with egg production. Poult Sci. 2006;85(1):26-31.

6. Panda B, Mahapatra SC. Common breeds of poultry in Poultry Production. India: ICAR; 1989. p. 6-18.

7. Bhatti MA, Qureshi MS, Ahmad A. Comparative study on the performance of various genetic groups of Aseel and its crosses with exotic breeds of poultry under controlled \& field conditions in Second Annual Report, Pakistan. Pakistan: Agric Res Council Islamabad; 1991.

8. Montgomery GW, Sise JA. Extraction of DNA from sheep white blood cells. New Zealand J Agric Res. 1990;33(3):437-441.

9. Rashidi H, Rahimi Mianji GH, Farhadi A, et al. Association of prolactin and prolactin receptor gene polymorphisms with economic traits in breeder hens of indigenous chickens of Mazandaran province. Iranian Journal of Biotechnology Thatching. 2012;10(2):129-135.

10. Mohan J, Sastry KVH, Tyagi JS. Production and other characteristics of Aseel Peeladesi hens under normal rearing system. Ind J Poult Sci. 2008;43:243-246.

11. Gurung BS, Singh M. Network project on Survey of poultry (Aseel) genetic sciences. India: ICAR Terminal Report; 1999.

12. Ahmad S, Hussain J, Akram M, et al. Comparative study on productive performance and hatching traits of three age groups of indigenous Mushki Aseel chickens. Agricultural Advances. 2013;2(5):146-149.

13. Singh CB, Singh CV. Selection indices for genetic improvement of broiler. Ind J Ani Res. 2008;42(2):125-127.

14. Haunshi S, Padhi MK, Niranjan M, et al. Comparative evaluation of native breeds of chicken for persistency of egg production, egg quality and biochemical traits. Ind J Anim Sci. 2013;83(1):59-62.

15. Zhang L, Li DY, Liu YP, et al. Genetic effect of the prolactin receptor gene on egg production traits in chickens. Genet Mol Res. 2012;11(4):43074315. 